\title{
Kadar Logam Berat Pb dan Histopatologi Limpa Sapi Bali yang Dipelihara di Tempat Pembuangan Akhir Suwung Denpasar
}

\author{
(LEVELS OF HEAVY METALS PB AND HISTHOPATHOLOGY OF SPLEEN OF THE BALI \\ CATTLE MAINTAINED IN SUWUNG DENPASAR FINAL DISPOSAL SITE)
}

\author{
Wahyu Semadi Putra ${ }^{1}$, I Ketut Berata ${ }^{2}$, I Made Kardena ${ }^{2}$ \\ ${ }^{1}$ PT Ciomas Adisatwa Wilayah Bali \\ ${ }^{2}$ Laboratorium Patologi Veteriner Fakultas Kedokteran Hewan, Universitas udayana \\ Jalan PB Sudirman, Denpasar \\ Email:wahyusemadi11@gmail.com
}

\begin{abstract}
ABSTRAK
Sapi bali yang dipelihara di Tempat Pembuangan Akhir (TPA) Suwung Denpasar, memanfaatkan sampah organik dan anorganik sebagai sumber pakan. Sampah tersebut dicurigai terkontaminasi logam berat $\mathrm{Pb}$. Penelitian ini bertujuan untuk mengetahui kadar $\mathrm{Pb}$ dan perubahan histopatologi limpa sapi bali yang dipelihara di TPA tersebut. Sampel berupa limpa diambil dari 5 ekor sapi untuk pemeriksaan logam berat $\mathrm{Pb}$ dengan metode Atomic Absorption Spectrofotometri dan pembuatan preparat organ limpa dengan pewarnaan Hematoxilin-Eosin. Hasil pemeriksaan menunjukkan adanya cemaran logam berat $\mathrm{Pb}$ yang bervariasi yaitu 1,5024 ppm, 1,5002 ppm, 2,0267 ppm, 2,0268 ppm, dan 0,6818 ppm. Pengamatan mikroskopis menunjukkan adanya perubahan histopatologi berupa deplesi dan proliferasi sel-sel limfoid.
\end{abstract}

Kata kunci: logam berat $\mathrm{Pb}$; limpa; sapi bali; deplesi; proliferasi

\begin{abstract}
Bali cattle eats organic and inorganic waste in Suwung Denpasar landfill as source of feed. The waste was suspected contaminated by heavy metals $\mathrm{Pb}$. The aim of this study is to determine levels of heavy metals $\mathrm{Pb}$ and spleen histopathologic changes of bali cattle reared in Suwung Denpasar landfill. Spleen samples were collected from 5 cattle for examination of heavy metals $\mathrm{Pb}$ by Atomic Absorption Spectrofotometri method and histopathology preparations made by HematoxilinEosin staining. The results showed the presence of heavy metal $\mathrm{Pb}$ contamination which varied of $1.5024 \mathrm{ppm}, 1.5002 \mathrm{ppm}, 2.0267 \mathrm{ppm}, 2.0268 \mathrm{ppm}$ and $0.6818 \mathrm{ppm}$. Microscopically, showed histopathological changes the form of depletion and proliferation of lymphoid cells.
\end{abstract}

Keywords: heavy metals $\mathrm{Pb}$; spleen; bali cattle; depletion; proliferation

\section{PENDAHULUAN}

Sapi bali memiliki keunggulan diantaranya mempunyai persentase karkas yang tinggi, kadar lemak daging yang rendah, dan mampu memanfaatkan pakan berkualitas rendah, serta memberikan respon cukup baik (Handiwirawan dan Subandriyo, 2004; Ris et al., 2012). Sapi bali memiliki daya adaptasi tinggi terhadap lingkungan. Hal ini ditemukan pada sapi bali yang dipelihara di daerah Timur Bali (Kubu, Tianyar, Seraya Timur) dan Nusa Penida (Tim Pusat Kajian Sapi Bali-Unud, 2012).
Sapi bali di pedesaan umunya digembalakan di lahan tegalan yang memiliki hijauan yang cukup (Sujani, et al., 2014). Kondisi berbeda ditemukan di perkotaan banyak peternak melepas ternak sapinya di tempat pembuangan sampah atau lebih dikenal dengan tempat pembuangan akhir (TPA). Sampah TPA perkotaan sangat potensial mengandung bahan anorganik yang berbahaya termasuk logam berat. Hasil penelitian Berata et al (2015) melaporkan bahwa di dalam darah sapi yang dipelihara di TPA Suwung Kota Denpasar mengandung logam berat $\mathrm{Pb}$ sampai melebihi batas atas ketentuan SNI- 
2009 yaitu 2,0 ppm. Sementara itu Sudiyono (2011) melaporkan sapi yang dipelihara di TPA Jatibarang Semarang, mengandung logam berat pada organ visceralnya.

Limpa merupakan merupakan organ pertahanan yang sangat berpotensi tercemar logam berat $\mathrm{Pb}$. Limpa memiliki peranan penting sebagai organ pertahanan tubuh yang berkaitan dengan respon imunologi terhadap antigen yang berasal dari luar melalui peredaran darah, sebagai penyaring darah, menyimpan zat besi untuk dimanfaatkan kembali dalam sintesis hemoglobin, memproduksi limfosit, dan antibodi (Khan et al., 2003). Mengingat peran ini, maka gangguan limpa oleh cemaran logam berat akan dapat berakibat pada gangguan kesehatan tubuh sapi secara keseluruhan. Hasan et al. (2013) melaporkan adanya residu logam berat $\mathrm{Pb}$ pada limpa sapi yang masih segar pada beberapa toko penjualan daging di Kota Ziffa dan Tanta wilayah Gharbia, dengan kadar rata-rata $0,57 \mathrm{ppm}$.

Hasil penelitian tersebut menandakan bahwa cemaran logam berat $\mathrm{Pb}$ dalam jaringan limpa sangat penting dikaji karena sebagai organ pertahanan tubuh bagi hewan, dan bagi masyarakat yang mengkonsumsi jeroan terutama organ limpa, sama-sama berbahaya. Oleh karena itu tujuan penelitian adalah untuk mengetahui kadar cemaran logam berat $\mathrm{Pb}$ dan perubahan histopatologi pada limpa sapi bali yang dipelihara di TPA Suwung Kota Denpasar.

\section{METODE PENELITIAN}

\section{Sampel Penelitian}

Sampel yang digunakan sebanyak 5 ekor sapi bali yang dipelihara di TPA. Sapi sampel dipotong di Rumah Potong Hewan Dharmasaba, Kabupaten Badung - Bali. Organ limpa diambil kemudian dibagi menjadi 2 bagian yaitu 1 bagian seberat 15 $\mathrm{g}$ untuk pengukuran kadar logam berat $\mathrm{Pb}$, sedangkan 1 bagian lainnya diproses pembuatan preparat histopatologi.

\section{Pengukuran Logam Berat $\mathbf{P b}$}

Pengukuran logam berat $\mathrm{Pb}$ pada jaringan limpa disesuaikan dengan metode pengukuran logam berat $\mathrm{Pb}$ menurut Irasanti et al., (2012) menggunakan metode Atomic Absorption Spectrofotometri (AAS). Pembacaan dilakukan dengan alat spektrofotometer serapan atom graphite fumace pada panjang gelombang 288,3 $\mathrm{nm}$ untuk logam $\mathrm{Pb}$.

\section{Pembuatan Preparat Histopatologi}

Proses Pembuatan preparat histopatologi jaringan limpa dengan metode Kiernan (2010). Sampel dimasukkan ke dalam Neutral Buffer Formalin 10\%, kemudian diproses di dalam tissue processor untuk dibuat preparat. Preparat diwarnai dengan pewarnaan Hematoxilin-Eosin (HE). Pengamatan sediaan dilakukan menggunakan mikroskop cahaya binokuler masing-masing dengan pembesaran 400x.

\section{Analisis Data}

Data hasil pengukuran kadar logam berat dan perubahan histopatologi yang diperoleh ditabulasi dan selanjutnya dianalisis dengan analisis deskriptif kualitatif.

\section{HASIL DAN PEMBAHASAN}

Hasil

Pengukuran kadar logam berat $\mathrm{Pb}$ dari 5 sampel limpa sapi bali, diperoleh hasil secara keseluruhan positif mengandung logam berat $\mathrm{Pb}$, dan disajikan pada Tab. 1 .

Tabel 1. Kadar Logam Berat Pb Limpa Sapi Bali yang Dipelihara di TPA Suwung Denpasar (ppm)

\begin{tabular}{ccc} 
No. Sapi & Kadar Pb & SNI (ppm) \\
\hline 1 & 1,5024 & 2,0 \\
2 & 1,5002 & 2,0 \\
3 & 2,0267 & 2,0 \\
4 & 2,0268 & 2,0 \\
5 & 0,6818 & 2,0 \\
\hline
\end{tabular}


Berdasarkan data kandungan logam berat $\mathrm{Pb}$ dari ke 5 sapi sampel, diperoleh hasil yang bervariasi yaitu masing-masing 1,5024 ppm, 1,5002 ppm, 2,0267 ppm, $2,0268 \mathrm{ppm}$, dan $0,6818 \mathrm{ppm}$. Nilai kandungan logam berat $\mathrm{Pb}$ yang ada dalam limpa sapi bali no. 3 dan no. 4 tampak melampaui batas maksimum cemaran logam berat dalam pangan menurut Standar Nasional Indonesia (SNI-2009), dimana kosentrasi kadar maksimum yang diperbolehkan sebesar 2,0 ppm (Tabel 1). Kandungan logam berat $\mathrm{Pb}$ yang melampaui batas maksimum yang ditetapkan SNI, maka organ tersebut tidak aman untuk dikonsumsi oleh manusia. Logam berat $\mathrm{Pb}$ dalam tubuh hewan maupun manusia dilaporkan bersifat akumulatif atau efeknya bersifat kronis (Sumah dan Aunurohim, 2013). Pengaruh logam berat $\mathrm{Pb}$ juga mengganggu metabolisme unsur nutrisi dalam tubuh yang diakibatkan oleh interaksinya dengan unsur esensial (Darmono, 1999)

\section{Pembahasan}

Adanya kandungan logam berat $\mathrm{Pb}$ pada limpa sapi bali yang cukup tinggi disebabkan faktor pakan maupun minuman. Sapi bali yang dipelihara di Tempat Pembuangan Akhir (TPA) Suwung Kota Denpasar sangat mungkin terkontaminasi logam berat $\mathrm{Pb}$. Hal yang sama dilaporkan oleh Sudiyono dan Handayanta, (2010) sampah yang dimanfaatkan sebagai sumber pakan sapi potong di Tempat Pembuangan Akhir (TPA) Sampah Putri Cempo Surakarta telah tercemar logam berat $\mathrm{Pb}$ sebesar $12,34 \mathrm{ppm}$.

Logam berat $\mathrm{Pb}$ yang masuk melalui saluran pencernaan akan diabsorbsi di usus, kemudian masuk ke dalam sirkulasi darah, berikatan dengan protein darah yang selanjutnya didistribusikan ke seluruh jaringan tubuh (Swaileh et al., 2009). Selama dalam sirkulasi darah, logam berat $\mathrm{Pb}$ 90\% terikat pada sel darah merah. Logam berat $\mathrm{Pb}$ yang masuk ke dalam
DOI: 10.24843/bulvet.2018.v10.i01.p10

tubuh tidak semua dapat tinggal di dalam tubuh. Sebesar 5\% - 10\% dari jumlah yang tertelan akan diabsorbsi oleh saluran pencernaan dan sekitar 5\% dari 30\% yang terserap lewat pernafasan akan tinggal di dalam tubuh (Kafiar et al., 2013). Proses distribusi memungkinkan zat atau metabolitnya sampai pada organ atau jaringan dan berakumulasi sehingga menyebabkan adanya residu logam berat $\mathrm{Pb}$ di dalam tubuh termasuk di limpa.

Faktor-faktor yang dapat mempengaruhi kandungan $\mathrm{Pb}$ dalam jaringan tubuh, antara lain: (1) umur, dimana semakin tua maka kandungan $\mathrm{Pb}$ semakin tinggi (sapi yang diteliti baru berumur 2 tahun, relatif masih muda, sehingga akumulasi $\mathrm{Pb}$ belum tinggi), (2) jenis jaringan tubuh, dimana urutan kandungan $\mathrm{Pb}$ dalam jaringan dari yang paling tinggi adalah: tulang, hati, paruparu, ginjal, limpa, jantung, otak, gigi, rambut (Suyanto et al., 2010).

Tabel 2. Histopatologi Limpa Sapi Bali yang Dipelihara di Tempat Pembuangan Akhir (TPA) Suwung Denpasar

No. Sapi Deplesi Proliferasi

\begin{tabular}{lll}
\hline 1 & + & - \\
2 & - & + \\
3 & - & + \\
4 & - & + \\
5 & - & + \\
\hline
\end{tabular}

Hasil pemeriksaan mikroskopis jaringan limpa, ditemukan adanya perubahan berupa deplesi sel-sel limfoid pada sapi no. 1 yang terlihat adanya peluruhan sel-sel limfoid. Sedangkan jaringan limpa pada sapi no. 2, 3, 4, dan 5 mengalami perubahan berupa proliferasi sel-sel limfoid. Deferensiasi dan pembelahan sel yang mengalami peningkatan, dimana pada pulpa putih terlihat adanya dominasi sel limfosit $\mathrm{T}$. Menurut Darlina et al. (2012) menyatakan limfosit yang mengalami stimulasi akan terjadi perubahan biokimia maupun 
morfologis. Secara biokimia terjadi perubahan kecepatan metabolisme oksidatif, sintesa protein dan RNA. Secara morfologis terjadi perubahan berupa transformasi blast dengan tanda-tanda diameter sel bertambah, kromatin sel blast menjadi longgar dan terwarnai pucat. Perubahan histopatologi limpa pada Tab. 2 dan gambarnya disajikan pada Gambar 1.
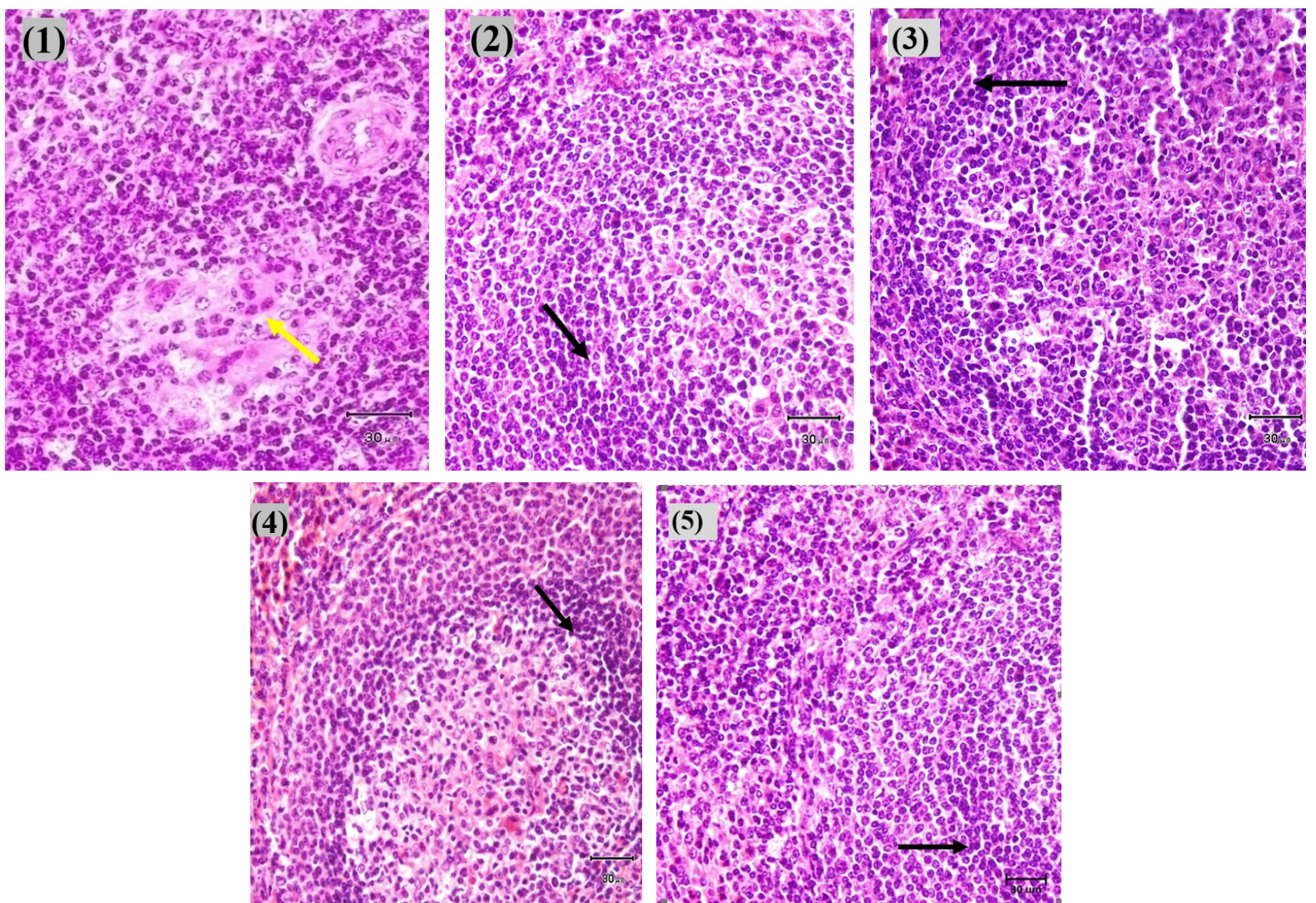

Gambar 1. Struktur limpa sapi TPA, ditemukan adanya perubahan deplesi sel limfoid (tanda panah kuning) dan adanya proliferasi sel-sel limfoid (tanda panah hitam) pada sapi 1, 2, 3, 4 dan 5 (400X, HE)

Struktur histologi limpa sapi bali tersusun atas kapsula, pulpa putih dan pulpa merah (Setiasih et al., 2011). Hasil pemeriksaan 5 sampel limpa sapi bali ditemukan adanya perubahan histopatologi berupa deplesi dan proliferasi sel-sel limfoid. Berkaitan dengan toksisitas logam berat $\mathrm{Pb}$, banyak studi menyatakan kerusakan sel erat kaitannya dengan stres oksidatif dan mekanisme ion. Monisha et al., (2014) menyatakan bahwa stres oksidatif pada sel terjadi apabila terdapat radikal bebas yang tinggi. Radikal bebas dalam hal ini ion $\mathrm{Pb}$ akan terjadi reaksi dengan antioksidan yang menyebabkan peningkatan produksi Reactive Oxygen Species (ROS) seperti hydroxyl radical
$\left(\mathrm{HO}^{-}\right)$, superoxide radical $\left(\mathrm{O}_{2}^{-}\right)$, atau hydrogen peroxide $\left(\mathrm{H}_{2} \mathrm{O}_{2}\right)$. Tingginya ROS dapat menyebabkan kondisi yang disebut "stres oksidatif". Sel dalam kondisi stres oksidatif dapat menyebabkan kerusakan struktur sel, protein, asam nukleat, lipid.

Mekanisme ion toksisitas logam berat $\mathrm{Pb}$ dalam organ limpa terjadi dalam darah. Ketika terjadi kenaikan kadar logam berat $\mathrm{Pb}$ dalam darah, ion $\mathrm{Pb}^{2+}$ akan berdifusi melewati selaput otak yang memiliki peranan yang sangat penting dalam menjaga sistem saraf. Selaput otak sangat selektif, dimana hanya molekul tertentu yang dapat berdifusi seperti kalsium, asam amino esensial, kalium dan 
natrium untuk dibawa ke dalam membran sel. Ion $\mathrm{Pb}^{2+}$ dalam sel dapat menggantikan kalsium $\left(\mathrm{Ca}^{2+}\right)$, dimana konsentrasi kalsium umumnya meningkat melalui 2 cara yaitu membukanya jalur kalsium dalam membran sel atau pelepasan kalsium yang disimpan dalam retikulum endoplasma. Hal ini menyebabkan stimulasi G-protein. Logam berat $\mathrm{Pb}$ kemudian masuk ke dalam sel melalui jalur kalsium dan berikatan dengan Calmodulin (CaM). Infiltrasi $\mathrm{Pb}$ ini akan memberikan pengaruh dan menstimulasi banyak fungsi intraseluler seperti peradangan, apoptosis, kontraksi otot, pertumbuhan saraf dan respon imun (Brochin et al., 2008).

Deplesi sel-sel limfoid yang ditemukan pada organ limpa sapi bali berpotensi disebabkan oleh logam berat $\mathrm{Pb}$ melaui mekanisme stres oksidatif. Kerusakan yang terjadi pada membran sel secara kronis dapat menyebabkan sel-sel mengalami nekrosis yang sangat mempengaruhi tingkat deplesi pada sel limfoid. Berdasarkan penelitian Muselin et al. (2010) ditemukan adanya perubahan berupa nekrosis pada organ limpa mencit akibat adanya paparan logam berat $\mathrm{Pb}$ secara terus menerus selama 6 bulan dengan total kadar logam berat $\mathrm{Pb}$ sebesar 3000 ppm.

Respon proliferasi yang terjadi merupakan proses diferensiasi dan pembelahan sel secara mitosis. Sebagai salah satu organ limfoid, limpa merupakan tempat terjadinya penangkapan antigen oleh sel-sel imunokompeten. Pada setiap saat sel-sel imunokompeten di dalam tubuh hewan selalu berhadapan dengan antigen yang masuk. Proliferasi sel limfosit yang diuji pada sistem in vitro dapat digunakan untuk menggambarkan fungsi limfosit dan merupakan salah satu parameter yang dapat digunakan untuk mengukur status imunitas, karena proliferasi limfoid menunjukkan kemampuan dasar dari sistem imun (Fletcher et al., 1994). Untuk dapat berproliferasi dan menghasilkan sel efektor atau sel imunokompeten, membran sel limfosit harus berada dalam kondisi utuh. Proliferasi sel bermula dari kontak antara membran sel dengan molekul aktivator. Apakah proliferasi sel-sel limfoid akibat cemaran logam berat $\mathrm{Pb}$ atau akibat agen infeksius, maka perlu diteliti lebih lanjut.

\section{SIMPULAN DAN SARAN}

\section{Simpulan}

Logam berat $\mathrm{Pb}$ limpa sapi bali yang dipelihara di Tempat Pembuangan Akhir (TPA) telah melewati batas maksimum cemaran 2,0267 ppm dan 2,0268 ppm. Dengan gambaran histopatologi limpa berupa deplesi dan proliferasi sel-sel limfoid.

Saran

Perlu dilakukan penelitian kandungan logam berat lainnya pada sapi yang dipelihara di Tempat Pembuangan Akhir (TPA) Suwung Denpasar.

\section{UCAPAN TERIMA KASIH}

Terimakasih kepada Pemda Kota Denpasar, RPH Darmasaba, Kepala Laboratorium Patologi FKH Unud dan Kepala Laboratorium Analitik Unud, atas bantuan fasilitas untuk penelitian.

\section{DAFTAR PUSTAKA}

Berata IK, Susari NNW, Kardena IM. 2015. Mendeteksi Logam Berat Pb dan Cd Pada Darah Sapi yang Dipelihara di TPA Suwung Denpasar. Prosiding Lembaga Penelitian dan Pengabdian kepada Masyarakat. Denpasar.

Brochin R, Leone S, Phillips D, Shepard N, Zisa D, Angerio A. 2008. The Cellular Effect of Lead Poisoning and Its Clinical Picture. The Georgetown Undergraduate J. Health Sci. 5(2).

Darlina, Kisnanto T, Mailani, W. 2012. Proliferasi Limfosit Mencit yang Diimunisasi dengan Plasmodium Berghei Radiasi 175 Gy. Prosiding Pertemuan dan Presentasi Ilmiah Penelitian Dasar Ilmu Pengetahuan dan Teknologi Nuklir. Yogyakarta. 
Darmono. 1999. Interaksi Logam Toksik dengan Logam Esensial dalam Sistem Biologik dan Pengaruhnya Terhadap Kesehatan Ternak. Wartazoa. 9(1).

Fletcher MA, Klimas N, Morgan R, Gjerset G. 1994. Lymphocyte Proliferation. Di dalam: Rose, N.R., deMacario, E.C., Fahey, J.L., Friedman, H., Penn, G.M. Manual Clinical Laboratory Immunology. $4^{\text {th }}$ Ed. Pp: 213-219.

Handiwirawan E, Subandriyo. 2004. Potensi dan Keragaman Sumber Daya Genetik Sapi Bali. Wartazoa. 14(3).

Hassan MA, Reham A, Amina, ElEkhnawy KI, Naglaa AB, El-Taibb. 2013. Heavy Metal Residues In Fresh and Ready - to - Eat Edible Offal. Benha Vet. Med. J. 24(1): 116-116.

Irasanti M, Santi DN, Dharma S. 2012. Analisis Kadar Timbal $(\mathrm{Pb})$ pada Hati Sapi dan Peternakan Sapi Potong di Kabupaten Deliserdang Tahun 2012. 4(1): 1-6.

Kafiar FP, Setyono P, Handono AR. 2013. Analisis Pencemaran Logam Berat ( $\mathrm{Pb}$ dan $\mathrm{Cd}$ ) Pada Sapi Potong di Tempat Pembuangan Akhir (TPA) Sampah Putri Cempo Surakarta. J. Ekosains. 5(2).

Khan H, Pardehi M, Rind R, Misri M. 2003. Biometrical Study on Normal Spleen of Cattle. J. Anim. Vet. Adv. 2(2): 92-94.

Kiernan JA. 2010. General Oversight Stains for Histology and Histopatology, Education Guide: Special Stains and $H \& E 2^{\text {nd }}$. North America, Carpinteria, California: Dako. Pp: 29-36.

Monisha J, Tenzin T, Naresh A, Blessy BM, Krishnamurthy NB. 2014. Toxicity, Mechanism and Health Effects of Some Heavy Metals. Interdiscip Toxicol. 7(2): 60-72.

Muselin F, Alexandra T, Brezovan DA, Stancu, Snejana P. 2010. The Consequences of Chronic Exposure to Lead on Liver, Spleen, Lungs and
Kidney Arhitectonics in Rats. Lucrari Stiinlifice Med. Vet. 18(2).

Ris A, Suatha IK, Batan IW. 2012. Keragaman Silak Tanduk Sapi Bali Jantan dan Betina. Bul. Vet. Udayana. 4(2): 87-93.

Setiasih ENL, Suwiti NK, Suastika P, Piraksa IW, Susari WNN. 2011. Studi Histologi Limpa Sapi Bali. Bul. Vet. Udayana. 3(1): 9-15.

Standar Nasional Indonesia. 2009. Batas maksimum cemaran logam berat dalam pangan. SNI 7387:2009. ICS 67.220 .20

Sudiyono, Handayanta, E. 2010. Studi Potensi Tempat Pembuangan Akhir (TPA) Sampah "Putri Cempo" Surakarta Sebagai Sumber Pakan Sapi Potong. Caraka Tani. 25(1).

Sudiyono, 2011. Upaya Eliminasi Residu Logam Berat pada Sapi Potong yang Berasal dari Lokasi Tempat Pembuangan Akhir Sampah dengan Pemeliharaan Secara Konvensional. Sains Peternakan Vol. 9 (1)

Sujani, SDKN, Piraksa IW, Suwiti NK. 2014. Profil Mineral Magnesium dan Tembaga Serum Darah Sapi Bali yang Dipelihara di Lahan Tegalan. Bul. Vet. Udayana. 6(2).

Sumah Y, Aunurohim. 2013. Bioakumulasi Logam Berat Timbal $\mathrm{Pb})$ dan Hubungannya dengan Laju Pertumbuhan Ikan Mujair (Oreochromis Mossambicus). J. Sains dan Seni Pomits. 2(2).

Suyanto A, Kusmiyati S, Retnaningsih. 2010. Logam Berat dalam Daging Sapi yang Dipelihara di Tempat Pembuangan Sampah Akhir. J. Pangan dan Gizi. 1(1).

Swaileh MK, Abdulkhaliq A, Hussein RM, Matani M. 2009. Distribution of Toxic Metals in Organs of Local Cattle, Sheep, Goat and Poultry from the West Bank, Palestinian Authority. Bull. Environ. Contam. Toxicol. 83: 265-268. 